\title{
Consumer Attitudes toward Cosmetic Products Containing Stem Cells from Plants
}

\author{
Nantapat Nittayapongchai ${ }^{1}$
}

\begin{abstract}
- the purpose of this research were to study and compare the opinion consumers in

Bangkok Thailand towards cosmetic products containing stem cells from plants.in four aspects: product, price, place and promotion classified by sex; age; occupation; education background; monthly income; marital status and persons influenced them decided to buy cosmetic. The samples were 400 consumers. They consumed cosmetic products containing stem cells from plants. The questionnaire was designed by the researcher and used for collecting data. The statistic methods used for the analysis were percentage, mean, standard deviation, Independent t-Test and One-Way Analysis of Variance.

The results of this research can be revealed as follows:

1. The opinion of consumers in the whole and each aspect were suitable at high level.

2. There were statically significant difference in the whole and the aspect of place at .05 level.

3. There was no statistically significant difference in the whole aspect.

4. There were statistically significant different in the whole and the aspect of product at .05 level.

5. There were statistically significant difference in the whole and each aspect at .05 level for the opinion of consumers with difference monthly income.

6. There was no statistically significant difference in the whole and each aspect for the opinion of consumers with difference marital status.
\end{abstract}

Keywords-Consumer attitudes, cosmetic products, stem cells from plants.

\section{INTRODUCTION}

Cosmetic products meant for use on skin preparations. Or any part of the body using massage lotion or spray, sprinkle with the aim of cleaning. Or foster beauty, or to change Cosmetics manner that is derived from a Greek word which means kosmetikos. Beautifully decorated to attract. From the spectator (the word means komos jewelry) in the early days as it used to be necessary. To suit the environment or nature. Cosmetics is an art that has since ancient times. Have discovered that Cosmetics have been used since ancient Egypt, China and India later date. The Greeks were the first nation to have a separate medical and cosmetics out of religious affairs. It also considered the use of cosmetics is important to treat the body in the correct uniform. Is routine

Nantapat Nittayapongchai ${ }^{1}$ Department of Economics, Faculty of Economics, Maejo University, Chiang Mai, Thailand 53000
Stem cells from plants Is part of the Bud Light The stem cells (Stem Cell) is capable of separating the cells, then grow new stem cells (Stem Cell) is a special feature.

1. Ability to create a new cell.

2. The ability to add or create a separate cell differently.

Stem cells from plants, so it is a powerful antioxidant. Can prevent cell damage by Hydrogen Peroxide in experiments. Cosmetic products from stem cell breakthroughs, as well as the placenta or plant cells. To extract more To increase the performance of the products we make up products that have overgrown plant tissue culture cells. Helps build more cells and extract information. That the surface Look younger instantly Thus, the current makeup of stem cells from plant stem cells from plants to play a role in the daily lives of more consumers. Market cosmetic stem cells from plant diversity, both in terms of price and quality can meet the needs of consumers. The new era of consumer attitudes and purchasing behavior cosmetic changes.

From the data above shows, buying cosmetic stem cells from plants to consumers are buying behavior and the factors in the decision to buy is different, so the researchers are interested in studying the attitudes of consumers. cosmetic stem cells from plants. For the purpose of planning, production and distribution of this product further.

\section{PURPOSE OF THE STUDY}

1. To study consumer attitudes toward cosmetic stem cells from plants to consumers in Bangkok.

2. To compare consumer attitudes toward cosmetic stem cells from plants. Demographic of consumers in Bangkok.

\section{HYPOTHESIS OF THE RESEARCH}

Demographic factors are Affects consumer attitudes toward cosmetic stem cells from plants to consumers in Bangkok different.

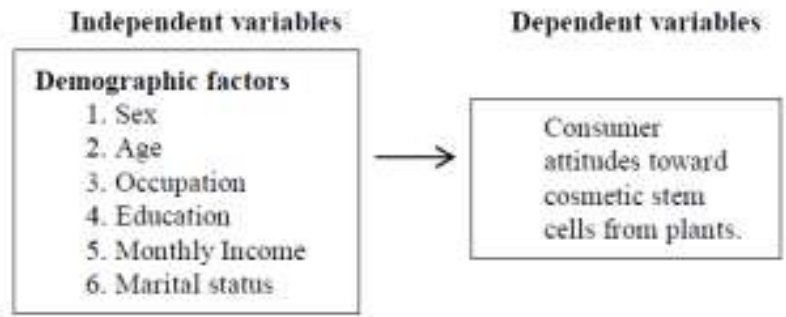

Fig. 1 Framework Research 


\section{SCOPE OF RESEARCH}

\section{Population and sample}

The population in this research include consumers in Bangkok. The samples used in the research. Including consumers who bought cosmetics from plant stem cells in total of 400 person.

\section{Period}

In doing the research is between March - June 2558.

3. Place

Data Collection in Bangkok

4. variable

4.1 Independent variables include demographic factors such as sex, age, occupation, education, income per month and marital status

4.2 dependent variable is the attitude of consumers towards cosmetic stem cell products from the plant in terms of price and distribution. And the promotion

\section{V.METHODS OF RESEARCH}

A. The study is a quantitative research. (Quantitative Research) research methods are as follows.

1. Population and sample consumers who bought cosmetics from plant stem cells in a total of 400 person by convenience sampling (Sample Sampling).

2. Tools used in the research

Tools used in research are questionnaires which researchers collect information from books. Various research papers associated To create a query that meets the objectives of the research. The content of the questionnaire is divided into three parts.

1. privacy of respondents.

2. consumer attitudes toward cosmetic stem cells from plants.

3. recommendations.

3. Finding quality research tools, including test validity (Validity) query by the IOC IOC (Index of congruence) is greater than 0.5 and credibility. (Reliability) by questionnaire was then revised to trial (Try Out) sample. A series of 30 experiments to the respondents before the actual data collection. Coefficient alpha Cronbach (Cronbach's Alpha Coefficient) of .89 .

4. The data were collected primary data (Primary Data) studied a questionnaire to determine the scope and content of the questionnaire. And secondary (Secondary Data) study of texts, documents, articles, and theoretical principles related research. To determine the extent of research and create a comprehensive, purpose of research.

5. The statistics used in this study consisted of descriptive statistics such as frequency, percentage, arithmetic. And standard deviation And inferential statistics, including statistics Independent sample t-test statistics and One way ANOVA (F-test).

\section{ConClusions}

Personal information of respondents found that the majority were female. 73.0 per cent aged 20-30 years accounted for 35.5 percent of bachelor's degree. 32.2 percent of Private Employees. 33.7 percent have a monthly income of 10,000 - 20,000 baht, representing 25.5 percent and 52.3 percent married.

Consumer attitudes toward cosmetic stem cell plants as a whole that influence buying decisions at many levels (mean 3.73), considering aspects that influence purchase decisions on price as high as possible. The second is the distribution. products And promotion, respectively, as detailed below. Product Overview Influence buying decisions at many levels (mean 3.68) factors affecting the tallest is always developing new products (mean 3.85) in overall price. Influence buying decisions at many levels (mean 3.79) factors affecting the highest cosmetic stem cell plants from direct selling cheaper than the cosmetic stem cells from plants to distribution. department store general (mean 4.06), the distribution as a whole. Influence buying decisions at many levels (mean 3.76) factors affecting the delivery of the highest (mean 4.09) the promotion as a whole. Influence buying decisions at many levels (mean 3.62) factors that affect the decision to have the highest promotions regularly (mean 3.76).

TABLE I

CONSUMER ATTITUDES TOWARDS COSMETIC STEM CELLS FROM PLANTS.

\begin{tabular}{|c|c|c|c|}
\hline $\begin{array}{c}\text { Consumer Attitudes towards } \\
\text { cosmetic stem cells from } \\
\text { plants }\end{array}$ & $\overline{\mathrm{X}}$ & S.D. & priority \\
\hline products & 3.68 & 0.92 & very \\
\hline price & 3.79 & 0.88 & very \\
\hline The distribution & 3.76 & 0.94 & very \\
\hline The promotion & 3.62 & 0.76 & very \\
\hline Overview & 3.73 & 0.90 & very \\
\hline
\end{tabular}

TABLE II

COMPARATIVE ANALYSIS OF CONSUMER ATTITUDES TOWARD COSMETIC STEM CELLS FROM PLANTS. DEMOGRAPHY

\begin{tabular}{|l|c|c|c|}
\hline \multirow{2}{*}{ The demographic } & \multicolumn{3}{|c|}{$\begin{array}{c}\text { Consumer attitudes toward cosmetic stem } \\
\text { cells from plants. }\end{array}$} \\
\cline { 2 - 4 } & $\mathrm{F}$ & Sig. & Interpret \\
\hline 1. Sex & 7.71 & $0.02^{*}$ & has results \\
\hline 2. Age & 14.07 & $0.00^{*}$ & has results \\
\hline 3. Occupation & 12.75 & 0.84 & no results \\
\hline 4. Education & 9.24 & $0.03^{*}$ & has results \\
\hline 5. Monthly Income & 8.60 & $0.00^{*}$ & has results \\
\hline 6. Marital status & 7.38 & $0.04^{*}$ & has results \\
\hline
\end{tabular}

* Indicates significance at the 0.05

\section{DISCUSSIONS}

Demographic factors such as gender, age, monthly income. Educational level and marital status Effect on consumer attitudes toward cosmetic stem cells from plants to consumers in Bangkok difference is statistically significant at 0.05, consistent with the research of a spa Blackie (2552) studied the attitudes and behavior of female consumers. teens in the East to buy cosmetics direct sales system. The research found that Consumers in adolescents between the East and 
the income derived from different parents. Attitudes to buy cosmetics direct sales system is different. Statistically significant at the 0.05 level and is also consistent with research Siriporn Bush relied on Buddhism (2548) studied the factors that are correlated with the consumption of cosmetics students. Rajamangala University of Technology Rattanakosin Poh Chang Campus The research found that Factors that influence the purchase decisions of students. B y charges received from parents as different. Significant statistically. 05.

\section{SUGGESTION}

1. Recommendations for the use of the results.

The study found that consumer attitudes toward cosmetic stem cell plants are the most price. The distribution products And the promotion of respective sample buy the product because there is always new. Cosmetic stem cell plants from direct sales of cosmetics are cheaper as compared to stem cells from a plant commonly sold in stores. The delivery of And the promotion regularly. The factors that influence the decision to buy low-quality products are developed continuously. A membership card to receive the discount rate, or the cosmetic stem cell plants are sold through online. Should the promotion of the awards upsell existing customers and attract a female, age 20-30 years of undergraduate study. Private Employees And have a monthly income of 10,000 20,000 baht to build a new customer base to more customers. Including payment via credit card online to ease even more.

2. Suggestions for research next time.

The researchers in this study of consumer attitudes toward cosmetic stem cells from plants to consumers in Bangkok only. Do not compare each brand cosmetic stem cells from plants. In the study, further studies should compare between brands cosmetic stem cells from plants. To understand the factors that influence the purchase decisions of each brand.

\section{REFERENCES}

[1] Khemika Prapunthong. (2552). Attitudes toward the purchase cosmetics imported from South Korea. Women in Bangkok

[2] Parichad Whantae. (2551). Consumer attitudes to import from overseas students. Chandrakasem Rajabhat University.

[3] Siriporn Pumpuengputh. (2548). Factors correlated with the consumption of cosmetics. Students of Rajamangala University of Technology Rattanakosin. Poh Chang campus. Journal of Education.

[4] Supranee junlaew. (2549). The attitude and behavior of the makeup of students in Bangkok.

[5] Saowaluck Wongraj. (2548). Factors affecting the decision to purchase cosmetic products.For skin whitening and wrinkle of women in the municipality. Lopburi. Thesis Master of Business Administration. Thepsatree's Rajabhat University.

[6] Amnuey Paeay. (2552). Consumer behavior, attitudes and adolescents in the East to buy. Direct sales of cosmetics. Accessed from http://journal.rru.ac.th/index.php/rajanagarindra/article/view/3/2 